\title{
PENGARUH KEPEMIMPINAN KEPALA DAN PERANAN KOMITE MADRASAH TERHADAP KINERJA GURU MADRASAH ALIYAH DI KABUPATEN BANJARNEGARA
}

\author{
Natir \\ Madrasah Aliyah Negeri 2 Banjarnegara \\ natir.spd@gmail.com
}

DOI : http://doi.org/10.37730/edutrained.v5i2.68

Diterima: 26 Juli 2020 | Disetujui: 28 November 2021 | Dipublikasikan: 20 Desember 2021

\begin{abstract}
Abstrak
Kepemimpinan kepala madrasah dan peranan komite madrasah merupakan dua faktor yang berpengaruh terhadap kinerja guru. Jenis penelitian ini adalah penelitian lapangan dengan teknik pengumpulan data menggunakan kuisioner dengan cara proportionate stratified random sampling. Sedangkan analisis data menggunakan metode deskriptif dan analisis regresi berganda. Hasil penelitian menunjukkan; 1 . terdapat pengaruh kepemimpinan kepala madrasah terhadapkinerja guru Madrasah Aliyah di Kabupaten Banjarnegara, dibuktikan dengan nilai T hitung sebesar 5,983 dengan signifikansi $0,000(p<0,05), 2$. terdapat pengaruh peranan komite madrasah terhadap kinerja guru Madrasah Aliyah di Kabupaten Banjarnegara, dibuktikan dengan nilai T hitung sebesar 3,704 dengan signifikansi $0,000(p<0,05), 3$. terdapat pengaruh kepemimpinan kepala madrasah dan peranan komite madrasah terhadap kinerja guru Madrasah Aliyah di Kabupaten Banjarnegara, dibuktikan dengan nilai $F$ hitung sebesar 87,501 dengan signifikansi 0,000 $(p<0,05)$. Kepemimpinan kepala madrasah merupakan faktor yang dominan pengaruhnya terhadap kinerja guru Madrasah Aliyah di Kabupaten Banjarnegara.
\end{abstract}

Kata Kunci: Kepemimpinan kepala Madrasah, peranan komite Madrasah, kinerja guru

\begin{abstract}
The leadership of the madrasa head and the role of the madrasa committee are two factors that influence teacher performance. The type of this research is a field research with data collection techniques using a questionnaire by means of proportionate stratified random sampling. While the data analysis use descriptive methods and multiple regression analysis. The results show that there are; 1) an influence of headmaster leadership on teacher performance by calculating T value of 5.983 with a significance of $0.000(p<0.05)$. 2) an influence of Madrasah committee's role on teacher performance of $T$ value of 3.704 with a significance of 0.000 ( $p<0.05)$, 3. an influence of headmaster leadership and Madrasah committee's role on Madrasah Aliyah teacher performance in Banjarnegara Regency of $F$ value of 87.501 with a significance of $0.000(p<0.05)$. The leadership of headmaster is the dominant factor influencing the performance of Madrasah Aliyah teachers in Banjarnegara Regency.
\end{abstract}

Keywords: Leadership of headmaster, the role of madrasah committee, teacher performance

This work is licensed under a Creative Commons Attribution-NonCommercial 4.0 International License

PENDAHULUAN

Keberhasilan guru dalam mengelola pembelajaran dibuktikan dengan tinggi rendahnya capaian indikator kinerja guru. Fattah dalam Sobirin bahwa kinerja atau prestasi kerja (performance) diartikan sebagai ungkapan kemampuan yang didasari oleh pengetahuan, sikap, keterampilan dan motivasi dalam 
menghasilkan sesuatu (2018:101). Kinerja guru adalah kualitas capaian atas pekerjaan yang diemban guru yang berbentuk pengetahuan, sikap dan keterampilan dengan didasarkan pada standar ukuran tertentu. Dengan kata lain, apabila perilaku guru memperoleh hasil pekerjaan yang sesuai dengan standar atau kriteria yang dibakukan oleh satuan pendidikan, maka kinerja guru yang bersangkutan tergolong baik, demikian berlaku sebaliknya.

Rendahnya kinerja guru dapat menyebabkan kualitas pembelajaran yang buruk. Buruknya kualitas pembelajaran dapat disebabkan oleh perencanaan pembelajaran yang kurang matang. Permasalahan ini masih mendominasi kondisi guru Madrasah Aliyah di Banjarnegara yang dibuktikan dengan fakta bahwa kecenderungan guru untuk menyalin perangkat pembelajaran yang dimiliki oleh sesama guru mapel yang sejenis dari madrasah lain masih cukup tinggi. Indikasi lain yang menguatkan rendahnya kinerja guru di Madrasah Aliyah di Banjarnegara adalah hampir sebagian besar guru masih menggunakan cara konvensional dalam mengajar yang ditandai dengan suasana belajar dimana dominasi guru masih sangat tinggi. Pemanfaatan media belajar yang relevan dengan bahan ajar belum dimaksimalkan karena metode pembelajaran yang digunakan masih berbasis ceramah. Selain itu, situasi belajar juga diperburuk dengan rendahnya penguasaan guru terhadap materi yang diajarkan kepada peserta didik.

Berdasarkan uraian tentang kondisi pembelajaran yang dilakukan oleh guru Madrasah Aliyah tersebut di Banjarnegara serta diperkuat dengan data yang diambil dari hasil supervisi pengawas pendidikan di madrasah periode 2018 - 2019, diperoleh gambaran tentang kinerja guru Madrasah Aliyah di Kabupaten Banjarnegara, sebagai berikut.

Tabel 1 Kinerja Guru Madrasah seKabupaten Banjarnegara (kompetensi pedagogik)

\begin{tabular}{|c|c|c|}
\hline No & Kinerja & $\begin{array}{l}\text { Rerata } \\
\text { Skor }\end{array}$ \\
\hline 1 & Guru mengenali karakteristik peserta & 63 \\
\hline 2 & $\begin{array}{l}\text { Guru menguasai teori belajar dan prinsip- } \\
\text { prinsip pembelajaran yang mendidik }\end{array}$ & 68 \\
\hline 3 & $\begin{array}{l}\text { Guru melakukan pengembangan } \\
\text { kurikulum }\end{array}$ & 58 \\
\hline 4 & $\begin{array}{l}\text { Guru melakukan kegiatan pembelajaran } \\
\text { vang mendidik }\end{array}$ & 69 \\
\hline 5 & $\begin{array}{l}\text { Guru memahami dan mengembangkan } \\
\text { potensi peserta didik }\end{array}$ & 56 \\
\hline 6 & $\begin{array}{l}\text { Guru mampu menciptakan komunikasi } \\
\text { yang efektif dengan peserta didik }\end{array}$ & 67 \\
\hline 7 & $\begin{array}{l}\text { Guru melakukan penilaian dan evaluasi } \\
\text { secara tuntas }\end{array}$ & 63 \\
\hline & Rata-rata & 63,43 \\
\hline
\end{tabular}

Sumber: Laporan kepengawasan madrasah tahun 2018-2019

Berikut merupakan kategori kualifikasi kinerja guru berdasarkan Permendiknas Nomor 35 Tahun 2010 tentang Petunjuk Teknis Pelaksanaan Jabatan Fungsional Guru dan Angka Kreditnya.

Tabel 2 Kinerja Guru

\begin{tabular}{ccc}
\hline Nilai Kinerja Guru & $\begin{array}{c}\text { Kualifikas } \\
\text { i }\end{array}$ & Sebutan \\
\hline $91-100$ & A & Amat Baik \\
$76-90$ & B & Baik \\
$61-75$ & C & Cukup \\
$51-60$ & D & Sedang \\
$\leq 50$ & E & Kurang \\
\hline
\end{tabular}

Sumber: Peraturan Menteri Pendidikan Nasional Nomor 35 Tahun 2010 tentang Petunjuk Teknis Pelaksanaan Jabatan Fungsional Guru dan Angka Kreditnya

Data yang telah diuraikan menunjukkan bahwa capaian kinerja guru Madrasah Aliyah di Banjarnegara masih berada dalam tingkatan rendah. Tinggi rendahnya capaian tersebut, tentu tidak terlepas dari faktor-faktor yang mempengaruhi. Faktor yang 
mempengaruhi kinerja guru dibedakan menjadi dua macam, yaitu faktor yang berasal dari dalam (internal) dan faktor yang berasal dari luar (eksternal). Faktor yang berasal dari dalam diri guru itu dapat berupa motivasi kerja guru dan kompetensi guru, sedangkan faktor yang berasal dari luar guru antara lain situasi lingkungan kerja seperti kepemimpinan kepala madrasah dan peranan komite madrasah.

Mengacu pada penelitian sebelumnya yang telah dipaparkan pada bagian pendahuluan, kepemimpinan kepala dan peranan komite madrasah merupakan dua faktor dari luar guru yang memiliki hubungan terdekat dengan situasi kerja guru. Tidak jauh berbeda dengan kondisi guru, kepala madrasah maupun komite madrasah juga memiliki indikasi yang sangat kuat bahwa mereka berdua sebagai bagian dari stakeholder di madrasah belum memberikan pengaruh yang optimal terhadap kinerja guru.

Gambaran secara umum kondisi kepala madrasah dan komite madrasah di Banjarnegara belum memperlihatkan kualitas kerja sebagaimana yang diharapkan oleh masyarakat. Berdasarkan observasi peneliti terdapat indikasi kepala madrasah belum sepenuhnya melaksanakan tupoksinya digambarkan seperti aktivitas kepala masih sebatas pada hal - hal rutinitas hadir di madrasah, menandatangani dokumen ataupun surat-surat yang diperlukan. Sisa waktu selebihnya belum terlihat kontribusi yang signifikan dengan kewenangannya untuk membangkitkan kinerja guru di madrasah yang dipimpinnya.

Berdasarkan observasi awal peneliti, komite madrasah dengan fungsi sebagai pengontrol (controlling agency) pendidikan di madrasah ternyata belum berjalan secara efektif. Komite madrasah sebagai mitra pendidikan, memiliki kecenderungan peranannya lebih banyak difokuskan pada persoalan bagaimana menggalang dana dari orang tua peserta didik. Fungsi dan peranan komite madrasah di sektor penjaminan mutu pendidikan justru terabaikan. Komite madrasah lebih banyak hadir atau dihadirkan di madrasah pada saat madrasah sedang memiliki kepentingan yang berkaitan dengan dana madrasah. Sebagai contoh, komite madrasah lebih sering dibutuhkan kehadirannya pada saat menjelang dan pelaksanaan rapat pleno rencana anggaran madrasah setiap tahunnya. Komite madrasah sepertinya lebih banyak dimanfaatkan fungsi anggaran daripada fungsi sebagi pengontrol pendidikan.

Melihat permasalahan yang telah diuraikan, peneliti tertarik mengadakan penelitian dalam masalah ini. Judul yang akan dijadikan sebagai bahan penelitian adalah "Pengaruh Kepemimpinan Kepala dan Peranan Komite Madrasah terhadap Kinerja Guru Madrasah Aliyah di Kabupaten Banjarnegara". Secara realistis pada saat seorang kepala dan komite madrasah belum dapat melaksanakan tugas pokok dan fungsinya secara maksimal maka akan berpengaruh terhadap rendahnya capaian kinerja guru. Untuk memenuhi harapan kinerja guru madarasah aliyah di Banjarnegara dengan kualitas kinerja yang bagus, kepemimpinan kepala dan peranan komite madrasah harus ditingkatkan secara maksimal.

Peneliti melakukan kajian pustaka terhadap penelitian sebelumnya yang relevan dengan penelitian. Kajian pustaka yang dijadikan pembanding dalam penelitian ini adalah lima penelitian. Penelitian pertama adalah penelitian yang dilakukan oleh Hanifudin Mahmud, S.Pd.I., mahasiswa pascasarjana UNSIQ, 
yang berjudul Model dan Pendekatan Supervisi Kepala Sekolah dalam Meningkatan Kinerja Guru PAI di SMP Negeri 1 Limpung Kabupaten Batang. Penelitian kedua adalah penelitian yang dilakukan oleh Triyantika Sari yang berjudul Pengaruh Peran Kepemimpinan Kepala Sekolah dan Peran Komite Sekolah Terhadap Kinerja Guru SD Negeri di Bandar Lampung. Penelitian ketiga adalah penelitian yang dilakukan oleh Carudin dengan judul Pengaruh Kepemimpinan Kepala Sekolah dan Iklim Kerja terhadap Kinerja Guru SMK Negeri se-Kabupaten Indramayu Tahun pelajaran 2010/2011. Penelitian keempat adalah penelitian yang dilakukan oleh Yusnidar dengan judul Kepemimpinan Kepala Madrasah dalam Meningkatkan Kinerja Guru pada Madrasah Aliyah Negeri Model Banda Aceh. Penelitian kelima adalah penelitian yang dilakukan oleh Taufik Ismail dengan judul Pengaruh Kepemimpinan Kepala Sekolah, Kompensasi, Motivasi Kerja, terhadap Kinerja Guru SD Negeri se-Kecamatan Ngamprah.

Berdasarkan pada kajian pustaka di atas, dijelaskan bahwa spesifikasi yang membedakan penelitian ini dari penelitian sebelumnya terlihat pada fokus penelitian. Kabupaten Banjarnegara dipilih oleh peneliti sebagai tempat pelaksanaan penelitian dengan responden penelitiannya adalah guru Madrasah Aliyah. Perbedaan tempat pelaksanaan penelitian dari peneliti sebelumnya akan diperoleh data penelitian yang belum tentu sama hasilnya dengan penelitian sebelumnya sehingga penelitian ini dapat dijaga keasliannya dari plagiasi terhadap hasil penelitian yang mendekati kemiripan dengan penelitian sebelumnya.

Kelemahan penelitian ini terletak pada proses pengambilan data.
Keterbatasan waktu, tenaga, serta biaya operasional penelitian yang cukup besar dijadikan sebagai alasan bagi peneliti untuk mengumpulkan data melalui kuesioner yang disebarkan kepada responden dan proses pengisian kuisonernya tidak disaksikan secara langsung oleh peneliti.

Berdasar pada uraian latar belakang masalah di atas, peneliti merumuskan beberapa permasalahan yang dapat diungkap melalui penelitian ini. Permasalahan tersebut dirumuskan sebagai berikut :

1. Bagaimana pengaruh kepemimpinan kepala madrasah terhadap kinerja guru Madrasah Aliyah di kabupaten Banjarnegara?

2. Bagaimana pengaruh peranan komite madrasah terhadap kinerja guru Madrasah Aliyah di kabupaten Banjarnegara?

3. Bagaimana pengaruh kepemimpinan kepala madrasah dan peranan komite madarasah terhadap kinerja guru Madrasah Aliyah di kabupaten Banjarnegara?

\section{KERANGKA TEORI}

1. Kepemimpinan Kepala

Sekolah/madrasah sebagai suatu lembaga pendidikan formal memiliki struktur yang terdiri dari kepala sekolah/madrasah, tenaga pendidik dan tenaga kependidikan serta peserta didik sebagai subjek belajar. Sesuai tugas pokok dan fungi masing-masing, semua kompenen bersinergi untuk mewujudkan tujuan pendidikan Nasional. Kepala madrasah merupakan pucuk pimpinan di madrasah. Sebagai pimpinan, ia memiliki fungsi yang sangat strategis dalam meningkatkan 
profesionalisme guru dan mutu pendidikan madrasah.

Kemendikanas

menyatakan kepala

sekolah/madrasah sebagai pimpinan

pendidikan harus mampu:

mendorong timbulnya kemauan yang kuat dengan penuh semangat dan percaya diri kepada guru, staf, dan peserta didik dalam melaksanakan tugasnya masing masing; (2) memberikan bimbingan dan mengarahkan guru - guru, staf, dan peserta didik serta memberi dorongan, memacu, dan berdiri di garda terdepan demi kemajuan dan memberi inspirasi di dalam mencapai tujuan.

2. Komite Madrasah

Menurut UU Nomor 20 Tahun 2003 Tentang Sistem Pendidikan Nasional khususnya pasal 56 ayat (3) disebutkan bahwa komite sekolah/madrasah, sebagai lembaga mandiri dibentuk dan berperan dalam peningkatan mutu pelayanan dengan memberikan pertimbangan, arahan, dan dukungan tenaga, sarana dan prasarana, serta pengawasan pendidikan pada tingkat satuan pendidikan.

\section{Kinerja Guru}

Pembelajaran merupakan roh institusi pendidikan yang kualitasnya wajib ditingkatkan secara terus menerus. Keberhasilan proses pendidikan di sekolah/madrasah sangat dipengaruhi oleh kinerja guru. Menurut Permendiknas Nomor 16 Tahun 2007 Tentang Standar Kualifikasi Akademik dan
Kompetensi Guru pasal 1 (1) disebutkan bahwa setiap guru wajib memenuhi standar kualifikasi akademik dan kompetensi guru yang berlaku secara nasional. Standar kompetensi guru ini dikembangkan secara utuh dari empat kompetensi utama, yakni kompetensi pedagogik, kepribadian, sosial, dan profesional. Keempat kompetensi utama tersebut terintegrasi dalam kinerja guru.

\section{Hipotesis}

Berdasarkan rumusan masalah yang telah diuraikan, dapat dirumuskan hipotesis penelitian sebagai berikut: Dengan mengoptimalkan kepemimpinan kepala dan peranan komite madrasah dapat:

H1 : diduga kepemimpinan kepala madrasah berpengaruh positif dan signifikan terhadap kinerja guru Madrasah Aliyah di kabupaten Banjarnegara,

H2 : diduga peranan komite madrasah berpengaruh positif dan signifikan terhadap kinerja guru Madrasah Aliyah di kabupaten Banjarnegara,

H3 : diduga kepemimpinan kepala madrasah dan peranan komite madrasah secara simultan berpengaruh positif dan signifikan terhadap kinerja guru Madrasah Aliyah di kabupaten Banjarnegara.

\section{METODE PENELITIAN}

Penelitian ini termasuk dalam penelitian kuantitatif. Penelitian kuantitatif didasarkan pada alasan ilmiah yakni data-data yang akan diolah dalam penelitian ini berupa angka-angka yang proses analisis datanya menggunakan statistik. Semiawan (2010) mengungkapkan bahwa metode penelitian kuantitatif adalah sebuah 
pendekatan dalam penelitian yang bersifat mengeneralisasikan sebuah fenomena yang ada, digunakan untuk membuktikan secara teori dan memiliki data berupa angka yang diuji menggunakan statistik.

Populasi dalam penelitian ini adalah guru Madrasah Aliyah se-Kabupaten Banjarnegara. Populasi penelitian sebanyak 367 orang, yang berasal dari 16 Madrasah Aliyah yaitu 2 Madrasah Aliyah negeri dan 14 Madrasah Aliyah swasta. Letak geografis Kabupaten Banjarnegara yang reliefnya tidak mudah dijangkau dalam waktu singkat, menyebabkan peneliti mengambil $50 \%$ populasi secara proportionate stratified random sampling yaitu 1 Madrasah Aliyah Negeri, dan 7 Madrasah Aliyah Swasta dengan jumlah sampel 170 orang. Mengacu pada tabel Isaac dan Michael (Sugiyono, 2010:126) besarnya sampel yang diambil adalah 114 orang guru.

Teknik pengumpulan data pada penelitian ini menggunakan teknik angket (kuisioner). Angket dalam penelitian ini mengungkap tiga variable penelitian, yaitu kepemimpinan kepala madrasah, peranan komite madrasah, dan kinerja guru. Dalam penelitian ini variabel kepemimpinan kepala sekolah/madrasah dibatasi hanya pada aspek manejerial, dan variabel kinerja guru dibatasi hanya aspek pedagogi saja. Variabel penelitian yang akan diukur dijabarkan menjadi indikator variabel yang selanjutnya akan dijadikan pedoman dalam pembuatan instrumen penelitian. Indikator penelitian disajikan pada tabel 3.

Tabel 3. Indikator InstrumenPenelitian

\begin{tabular}{|l|l|ll|}
\hline No & \multicolumn{1}{|c|}{ Variabel } & \multicolumn{1}{c|}{ Indikator } \\
\hline 1 & $\begin{array}{l}\text { Kepemimpinan } \\
\text { kepala } \\
\text { sekolah/madra } \\
\text { sah }\end{array}$ & 1. & $\begin{array}{l}\text { menyusun perencanaan Madrasah } \\
\text { dalam berbagai skala perencanaan; } \\
\text { mengembangkan Madrasah sesuai } \\
\text { dengan } \\
\text { kebutuhan; }\end{array}$ \\
\hline
\end{tabular}

\begin{tabular}{|c|c|c|}
\hline & & 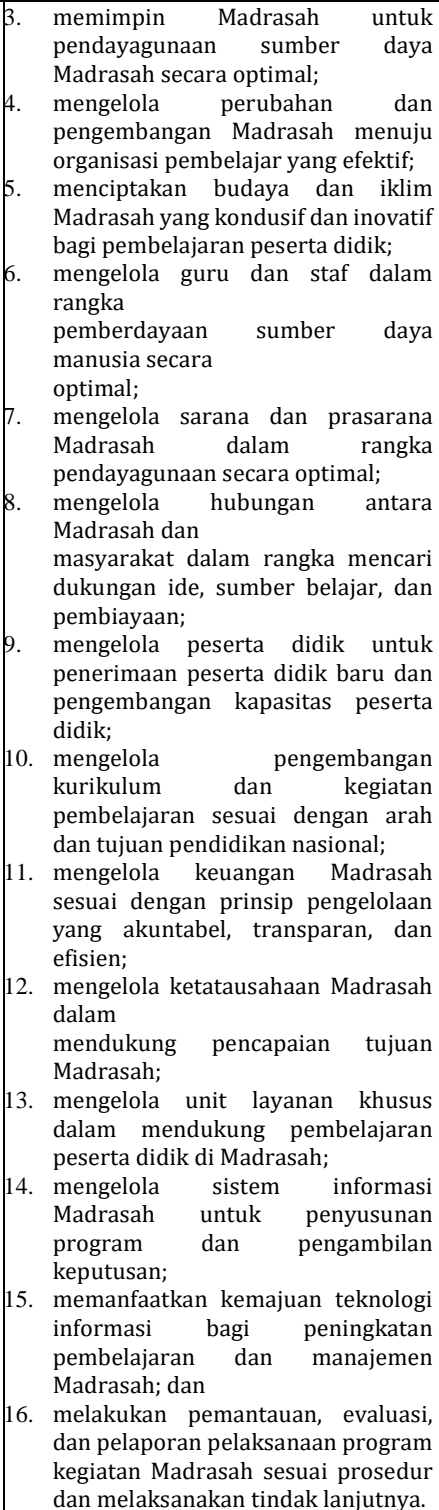 \\
\hline 2 & $\begin{array}{l}\text { Peranan } \\
\text { komite } \\
\text { sekolah/madra } \\
\text { sah }\end{array}$ & \begin{tabular}{|l} 
1. \\
memberikan pertimbangan dalam \\
penentuan dan pelaksanaan \\
kebijakan pendidikan; \\
menggalang dana dan sumber daya \\
pendidikan lainnya; \\
3. $\begin{array}{l}\text { mengawasi pelayanan pendidikan di } \\
\text { madrasah; }\end{array}$ \\
4. \\
menindaklanjuti keluhan, kritik dan \\
saran dari peserta didik serta \\
masyarakat.
\end{tabular} \\
\hline 3 & Kinerja guru & 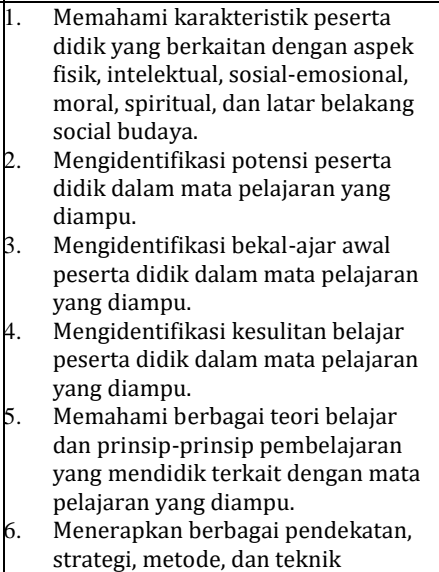 \\
\hline
\end{tabular}




\begin{tabular}{|l|l|}
\hline pembelajaran yang mendidik secara \\
kreatif dalam mata pelajaran yang \\
diampu.
\end{tabular}

\begin{tabular}{|l|l|}
\hline & $\begin{array}{l}\text { 28. } \\
\text { Melakukan refleksi terhadap } \\
\text { pembelajaran yang telah } \\
\text { dilaksanakan. }\end{array}$ \\
29. & $\begin{array}{l}\text { Memanfaatkan hasil refleksi untuk } \\
\text { perbaikan dan pengembangan } \\
\text { pembelajaran dalam mata pelajaran } \\
\text { yang diampu. } \\
\text { Melakukan penelitian tindakan } \\
\text { kelas untuk meningkatkan kualitas } \\
\text { pembelajaran dalam mata pelajaran } \\
\text { yang diampu. }\end{array}$ \\
\hline
\end{tabular}

Kualitas sebuah instrumen

penelitian harus diuji terlebih dahulu untuk mengetahui valid dan reliabel tidaknya instrument yang akan digunakan untuk mengambil data penelitian. Langkah-langkah ditempuh untuk menguji kualitas instrumen adalah melakukan uji validitas instrumen dan uji reliabilitas instrumen. Sebelum digunakan instrumen yang telah disusun diujicobakan kepada 30 responden. Hasil uji coba menunjukkan bahwa instrumen yang akan digunakan telah valid dan reliabel.

Setelah data penelitian terkumpul dilakukan analisis regresi berganda dan uji asumsi klasik. Analisis regresi berganda meliputi uji t yang bertujuan untuk menguji koefisien regresi secara individu, uji $\mathrm{f}$ yang bertujuan untuk mengetahui pengaruh variabel bebas secara bersama-sama terhadap variabel terikat, dan koefisien determinasi $(R$ Square) yang bertujuan untuk menjelaskan seberapa besar sumbangan variabel terhadap kinerja guru. Untuk menguji hipotesis dilakukan uji Regresi Berganda dengan toleransi kesalahan yang masih dapat diterima sebesar $5 \%$.

Analisis data terhadap penelitian kuantitatif dilakukan setelah seluruh data yang diperoleh dari responden atau sumber data terkumpul. Kegiatan dalam analisis data meliputi: mengelompokkan data berdasarkan variabel dan jenis responden, mentabulasi data berdasarkan variabel dari seluruh responden, menyajikan data dari variabel yang diteliti, melakukan penghitungan untuk menguji hipotesis yang telah diajukan (Sugiyono, 2010:207). 


\section{HASIL PENELITIAN DAN PEMBAHASAN}

\section{Data Hasil Penelitian}

Berdasarkan pada data penelitian tentang variabel kepemimpinan kepala madrasah, dapat di-resume bahwa hasil penelitian sebagai berikut.

Tabel 4 Tabel Frekuensi Variabel

Kepemimpinan Kepala Madrasah

\begin{tabular}{|c|c|c|c|c|c|}
\hline \multicolumn{6}{|c|}{ Kepemimpinan Kepala Madrasah } \\
\hline & & Frequency & Percent & $\begin{array}{c}\text { Valid } \\
\text { Percent }\end{array}$ & $\begin{array}{c}\text { Cumulative } \\
\text { Percent }\end{array}$ \\
\hline \multirow{6}{*}{ Valid } & $\begin{array}{l}\text { Sangat } \\
\text { Tinggi }\end{array}$ & 0 & 0 & 0 & 0 \\
\hline & Tinggi & 33 & 28.9 & 28.9 & 28.9 \\
\hline & Sedang & 57 & 50.0 & 50.0 & 78.9 \\
\hline & Rendah & 18 & 15.8 & 15.8 & 94.7 \\
\hline & $\begin{array}{l}\text { Sangat } \\
\text { Rendah } \\
\end{array}$ & 6 & 5.3 & 5.3 & 100.0 \\
\hline & Total & 114 & 100.0 & 100.0 & \\
\hline
\end{tabular}

Sumber data terolah 2019

Berdasarkan pada data penelitian peranan komite madrasah, dapat diresume bahwa hasil penelitian sebagai berikut.

Tabel 5 Tabel Frekuensi dari Variabel Peranan Komite Madrasah

\begin{tabular}{cccccc}
\hline \multicolumn{5}{c}{ Peranan Komite Madrasah } \\
\hline \multirow{1}{*}{$\begin{array}{l}\text { Sangat } \\
\text { Tinggi }\end{array}$} & 8 & 7.0 & 7.0 & 7.0 \\
\cline { 2 - 6 } & Frequency & Percent & $\begin{array}{c}\text { Valid } \\
\text { Percent }\end{array}$ & $\begin{array}{c}\text { Cumulative } \\
\text { Percent }\end{array}$ \\
\cline { 2 - 6 } Valid & 14 & 12.3 & 12.3 & 19.3 \\
\cline { 2 - 6 } & Sedang & 69 & 60.5 & 60.5 & 79.8 \\
\cline { 2 - 6 } & Rendah & 18 & 15.8 & 15.8 & 95.6 \\
\cline { 2 - 6 } & $\begin{array}{l}\text { Sangat } \\
\text { Rendah }\end{array}$ & 5 & 4.4 & 4.4 & 100.0 \\
\cline { 2 - 6 } & Total & 114 & 100.0 & 100.0 \\
\hline
\end{tabular}

Sumber data terolah 2019

Berdasarkan pada data penelitian variable kinerja guru Madrasah Aliyah dapat diresume bahwa hasil penelitian sebagai berikut.
Tabel 6 Tabel Frekuensi dari Variabel Kinerja Guru Madrasah Aliyah

\begin{tabular}{cccccc}
\hline \multicolumn{5}{c}{ Kinerja Guru Madrasah } \\
\hline & Frequency & Percent & $\begin{array}{c}\text { Valid } \\
\text { Percent }\end{array}$ & $\begin{array}{c}\text { Cumulative } \\
\text { Percent }\end{array}$ \\
\hline \multirow{5}{*}{ Kinerja } & $\begin{array}{l}\text { Sangat } \\
\text { Tinggi }\end{array}$ & 6 & 5.3 & 5.3 & 5.3 \\
\cline { 2 - 6 } & Tinggi & 28 & 24.6 & 24.6 & 29.8 \\
\cline { 2 - 6 } & Sedang & 39 & 34.2 & 34.2 & 64.0 \\
\cline { 2 - 6 } & Rendah & 39 & 34.2 & 34.2 & 98.2 \\
\cline { 2 - 6 } & $\begin{array}{l}\text { Sangat } \\
\text { Rendah }\end{array}$ & 2 & 1.8 & 1.8 & 100.0 \\
\cline { 2 - 6 } & Total & 114 & 100.0 & 100.0 & \\
\hline
\end{tabular}

Sumber data terolah 2019

Berdasarkan pada hasil uji statistik deskriptif dengan bantuan program SPSS versi 20 dapat diketahui sebagai berikut.

Tabel 7 Hasil Uji Statistik Deskriptif

\begin{tabular}{lccccc}
\hline & $\mathbf{N}$ & Minimum & Maximum & Mean & $\begin{array}{c}\text { Std. } \\
\text { Deviation }\end{array}$ \\
\hline $\begin{array}{l}\text { Kepemimpinan } \\
\begin{array}{l}\text { Kepala } \\
\text { Madrasah }\end{array}\end{array}$ & 114 & 3.00 & 5.00 & 4.2411 & .44258 \\
\hline $\begin{array}{l}\text { Peranan } \\
\text { Komite } \\
\text { Madrasah }\end{array}$ & 114 & 2.50 & 5.00 & 4.1105 & .47647 \\
\hline $\begin{array}{l}\text { Kinerja Guru } \\
\text { Madrasah }\end{array}$ & 114 & 3.51 & 5.00 & 4.2798 & .36020 \\
\hline $\begin{array}{l}\text { Valid N } \\
\text { (listwise) }\end{array}$ & 114 & & & & \\
\hline Sumber data terolah 2019 & & &
\end{tabular}

Sumber data terolah 2019

\section{Analisis Data}

\section{a. Deskripsi Variabel Penelitian}

Variabel penelitian terdiri dari total 110 item pernyataan yang terbagi menjadi 3 (tiga) variabel yaitu 1 (satu) variabel dependen dan 2 (dua) variabel independen. Kesesuaian jawaban dikategorikan dalam skala Sangat Setuju (SS), Setuju (S), Kurang Setuju (KS), Tidak Setuju (TS), dan Sangat Tidak Setuju (STS). Skor untuk pernyataan positif SS= $5, \mathrm{~S}=4, \mathrm{KS}=3$, TS=2, dan STS=1. Sebaliknya skor untuk pernyataan negatif $S S=1, S=2$, $\mathrm{KS}=3$, $\mathrm{TS}=4$, dan $\mathrm{STS}=5$. Untuk menjawab kecenderungan jawaban responden terhadap masing-masing variabel, akan didasarkan pada nilai skor rata-rata yang dikategorikan dalam rentang skor berdasarkan perhitungan rata-rata dan standar deviasi. Pengubahan skor menjadi skala lima tersebut menurut Anas Sudijono dikutip oleh Suparwati (2013: 74) dapat dilihat pada tabel 8. 
Tabel 8 Kriteria nilai

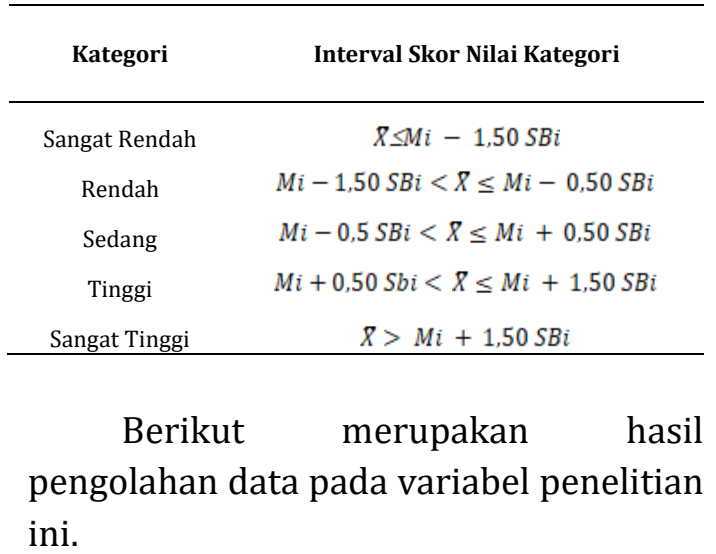

Tabel 9 Deskripsi Variabel Kepemimpinan Kepala Madrasah

\begin{tabular}{lccc}
\hline Kategori & Rentang skor & Frek & Persen \\
\hline $\begin{array}{l}\text { Sangat } \\
\text { Rendah }\end{array}$ & $\begin{array}{c}\mathrm{X}<120,56 \\
120,56<=\mathrm{X}< \\
139,14\end{array}$ & 6 & 5,26 \\
Rendah & $\begin{array}{c}139,14<=\mathrm{X}< \\
157,73\end{array}$ & 57 & 50,00 \\
Sedang & $\begin{array}{c}157,73<=\mathrm{X}< \\
=176,32\end{array}$ & 33 & 28,95 \\
Tinggi & $\mathrm{X}>176,32$ & 0 & 0,00 \\
$\begin{array}{l}\text { Sangat } \\
\text { Tinggi }\end{array}$ & 114 & 100 \\
\hline Total & & &
\end{tabular}

Sumber data terolah 2019

Tabel 9 menunjukkan tanggapan responden terhadap variabel kepemimpinan kepala madrasah. Kepemimpinan kepala madrasah lingkungan Madrasah Aliyah di kabupaten Banjarnegara menunjukkan kepemimpinan kepala madrasah kategori sedang sebanyak 50,00 persen, kategori tinggi sebanyak 28,95 persen, kategori rendah sebesar 15,79 persen, kategori sangat rendah 5,26 persen, dan nol persen untuk kepemimpinan kepala madrasah sangat tinggi.

Adapun deskripsi variabel peranan komite madrasah disajikan pada tabel berikut.
Tabel 10 Deskripsi Variabel Peranan Komite Madrasah

\begin{tabular}{llcc}
\hline Kategori & \multicolumn{1}{c}{ Rentang skor } & Frek & Persen \\
\hline Sangat & & & \\
Rendah & $\mathrm{X}<97,59$ & 5 & 4,39 \\
Rendah & $97,59<=\mathrm{X}<114,74$ & 18 & 15,79 \\
Sedang & $114,74<=\mathrm{X}<131,89$ & 69 & 60,53 \\
& $131,89<=\mathrm{X}<$ & & \\
Tinggi & $=149,05$ & 14 & 12,28 \\
Sangat & & & \\
Tinggi & $\mathrm{X}>149,05$ & 8 & 7,02 \\
\hline Total & & 114 & 100 \\
\hline
\end{tabular}

Sumber data terolah 2019

Tabel 10 menunjukkan tanggapan responden terhadap variabel peranan komite madrasah. Peranan komite madrasah di lingkungan Madrasah Aliyah di Kabupaten Banjarnegara menunjukkan peranan komite madrasah kategori sedang sebanyak 60,53 persen, kategori rendah sebanyak 15,79 persen, kategori tinggi sebesar 12,28 persen, kategori sangat tinggi sebesar 7,02 persen, dan kategori sangat rendah 4,39 persen.

Selain itu, deskripsi variabel kinerja guru madrasah disajikan pada tabel berikut.

Tabel 11 Deskripsi Variabel Kinerja Guru Madrasah

\begin{tabular}{|c|c|c|c|}
\hline Kategori & $\begin{array}{c}\text { Rentang } \\
\text { skor }\end{array}$ & Frek & Persen \\
\hline \multicolumn{4}{|l|}{ Sangat } \\
\hline Rendah & $\begin{array}{l}X<163,39 \\
163,39<=\end{array}$ & 2 & 1,75 \\
\hline Rendah & $\begin{array}{l}X<182,85 \\
182,85<=\end{array}$ & 39 & 34,21 \\
\hline Sedang & $\begin{array}{l}X<202,31 \\
202,31<= \\
X<\end{array}$ & 39 & 34,21 \\
\hline $\begin{array}{l}\text { Tinggi } \\
\text { Sangat }\end{array}$ & $=221,77$ & 28 & 24,56 \\
\hline Tinggi & $X>221,77$ & 6 & 5,26 \\
\hline Total & & 114 & 100 \\
\hline
\end{tabular}

Sumber data terolah 2019

Tabel 11 menunjukkan tanggapan responden terhadap kinerja guru madrasah. Kinerja guru madrasah di lingkungan Madrasah Aliyah di Kabupaten Banjarnegara menunjukkan kinerja guru madrasah kategori sedang sebanyak 34,21persen, kategori rendah sebanyak 34,21 perse,n kategori tinggi sebesar 12,28 persen, kategori sangat 
tinggi sebesar 5,26 persen, dan kategori sangat rendah 1,75 persen.

\section{b. Hasil Uji Statistik Deskriptif Variabel Penelitian}

Hasil statistik deskriptif dengan menggunakan bantuan program SPSS versi 20 dalam penelitian ini dapat dilihat pada tabel berikut.

Tabel 12 Uji Statistik Deskriptif

\begin{tabular}{lcccc}
\hline $\begin{array}{c}\text { Descriptive } \\
\text { Statistics }\end{array}$ & $\begin{array}{c}\text { Minim } \\
\text { um }\end{array}$ & $\begin{array}{c}\text { Maxim } \\
\text { um }\end{array}$ & $\begin{array}{c}\text { Me } \\
\text { an }\end{array}$ & $\begin{array}{c}\text { Std. } \\
\text { Deviation }\end{array}$ \\
\hline Kepemimpina & & & 4, & \\
n Kepala & 3 & 5 & 24 & 0,443 \\
Madrasah & & & 1 & \\
Peranan & & & 4, & \\
Komite & 2,5 & 5 & 11 & 0,476 \\
Madrasah & & & 0 & \\
& & & 4, & \\
Kinerja Guru & 3,51 & 5 & 27 & 0,360 \\
Madrasah & & & 9 & \\
\hline
\end{tabular}

Sumber data terolah 2019

Variabel kepemimpinan kepala madrasah memiliki nilai rata-rata minimal sebesar 3, nilai maksimal sebesar 5,0, nilai mean sebesar 4,241, dan standar deviasi sebesar 0,443. Variabel peranan komite madrasah memiliki jawaban rata-rata minimum responden sebesar 2,50 dan nilai maksimum sebesar 5,00 dengan mean sebesar 4,110 dan standar deviasi sebesar 0,476. Variabel kinerja guru madrasah memiliki nilai rata-rata minimal sebesar 3,51 dan nilai maksimal sebesar 5,00 dengan nilai mean sebesar 4,279 dan standar deviasi sebesar 0,360 .

\section{c. Asumsi Klasik Pengaruh Kepemimpinan Kepala Madrasah dan Peranan Komite Madrasah terhadap Kinerja Guru Madrasah Aliyah di Banjarnegara}

Uji asumsi klasik terdiri atas uji normalitas, uji multikolineritas, dan uji heteroskedatisitas. Uji normalitas data dimaksudkan untuk mengetahui apakah data yang digunakan dalam penelitian ini bersifat normal atau tidak. Hasil uji yang telah dilakukan adalah sebagai berikut.
Tabel 13 Uji Normalitas

\begin{tabular}{llc}
\hline & & $\begin{array}{c}\text { Standardized } \\
\text { Residual }\end{array}$ \\
\hline $\mathrm{N}$ & Mean & 114 \\
Normal Parameters ${ }^{\mathrm{a}, \mathrm{b}}$ & & 0,000 \\
& Std, Deviation & 0,991 \\
Most Extreme Differences & Absolute & 0,106 \\
& Positive & 0,106 \\
& Negative & $-0,071$ \\
Kolmogorov-Smirnov Z & & 1,137 \\
Asymp. Sig. (2-tailed) & & 0,151 \\
\hline
\end{tabular}

a. Test distribution is Normal.

b. Calculated from data.

Sumber data terolah 2019

Dari uji normalitas kolmogorovSmirnov didapatkan hasil nilai $\mathrm{Z}$ sebesar 1,137 dengan tingkat signifikan di atas 0,05 , yaitu 0,151 , diperoleh hasil Sig $(2$-tail $=0,151>\alpha(0,05)$. Dengan demikian, kurva nilai residual terstandarisasi dikatakan menyebar dengan normal, sehingga model regresi lolos uji asumsi normalitas.

Untuk menguji apakah dalam model regresi ditemukan adanya korelasi antar variabel bebas (independen). Salah satu cara mendeteksi adanya multikolinearitas adalah dengan melihat Tolerance dan Variance Inflasion Factor (VIF).

Tabel 14. Uji Multikolinearitas

\begin{tabular}{|l|l|c|c|c|c|}
\hline \multirow{2}{*}{$\begin{array}{l}\text { mod } \\
\text { el }\end{array}$} & & \multirow{2}{*}{ T } & sig & \multicolumn{2}{|c|}{ Collinearity Statistics } \\
\cline { 2 - 4 } & & & Tolerance & VIF \\
\hline 1 & (Constant) & 7,081 & 0,000 & & \\
\hline & $\begin{array}{l}\text { Kepemimp } \\
\text { inan } \\
\text { Kepala } \\
\text { Madrasah }\end{array}$ & 5,983 & 0,000 & 0,468 & 2,138 \\
\hline & $\begin{array}{l}\text { Peranan } \\
\text { Komite } \\
\text { Madrasah }\end{array}$ & 3,704 & 0,000 & 0,468 & 2,138 \\
\hline
\end{tabular}

\section{d. Pengujian Hipotesis Pengaruh Kepemimpinan Kepala Madrasah dan Peranan Komite Madrasah terhadap Kinerja Guru Madrasah Aliyah di Banjarnegara} berikut. 
Tabel 15 Hasil Uji T

\begin{tabular}{|c|c|c|c|c|c|c|}
\hline \multicolumn{7}{|c|}{$\begin{array}{l}\text { Coefficien } \\
\text { ts }^{\mathrm{a}}\end{array}$} \\
\hline \multirow[t]{2}{*}{$\begin{array}{l}\text { M } \\
o \\
d \\
e \\
\text { l }\end{array}$} & & \multicolumn{2}{|c|}{$\begin{array}{l}\text { Unstand } \\
\text { ardized } \\
\text { Coefficie } \\
\text { nts }\end{array}$} & $\begin{array}{l}\text { Standa } \\
\text { rdized } \\
\text { Coeffic } \\
\text { ients }\end{array}$ & \multirow[t]{2}{*}{$\mathrm{t}$} & \multirow[t]{2}{*}{ Sig. } \\
\hline & & B & $\begin{array}{c}\text { St } \\
\text { d. } \\
\text { Er } \\
\text { ro } \\
\text { r }\end{array}$ & Beta & & \\
\hline \multirow[t]{3}{*}{1} & $\begin{array}{l}\text { (Const } \\
\text { ant) }\end{array}$ & $\begin{array}{c}67 \\
3 \\
98\end{array}$ & $\begin{array}{l}9,5 \\
18\end{array}$ & & 7,081 & 0,000 \\
\hline & $\begin{array}{l}\text { Kepem } \\
\text { impina } \\
\mathrm{n} \\
\text { Kepala } \\
\text { Madra } \\
\text { sah }\end{array}$ & $\begin{array}{c}0 \\
54 \\
1\end{array}$ & $\begin{array}{c}0,0 \\
91\end{array}$ & 0,517 & 5,983 & 0,000 \\
\hline & $\begin{array}{l}\text { Perana } \\
\text { n } \\
\text { Komit } \\
\text { e } \\
\text { Madra } \\
\text { sah }\end{array}$ & $\begin{array}{c}0 \\
36 \\
3\end{array}$ & $\begin{array}{l}0,0 \\
98\end{array}$ & 0,32 & 3,704 & 0,000 \\
\hline
\end{tabular}

Berikut merupakan penjabaran tabel 15.

1) $\mathrm{T}$ hitung variabel kepemimpinan kepala madrasah sebesar 5,983 dengan nilai signifikansi 0,000 , yang berarti bahwa kepemimpinan kepala madrasah berpengaruh positif dan signifikan terhadap kinerja guru madrasah $(\mathrm{p}<0,05)$.

$\mathrm{T}$ hitung variabel peranan komite madrasah sebesar 3,704 dengan nilai signifikansi 0,000 , yang berarti bahwa peranan komite madrasah pengaruh positif dan signifikan terhadap kinerja guru madrasah $(\mathrm{p}<0,05)$.

Untuk menguji pengaruh kepemimpinan kepala madrasah, dan peranan komite madrasah secara langsung terhadap kinerja guru madrasah digunakan analisis regresi berganda, yakni uji f, uji t, dan koefisien determinasi. Hasil perhitungannya sebagai berikut.
Tabel 16 Hasil Uji F

\begin{tabular}{|c|c|c|c|c|c|c|}
\hline \multicolumn{7}{|c|}{ ANOVA $^{\mathbf{a}}$} \\
\hline \multicolumn{2}{|l|}{$\begin{array}{l}\text { Mod } \\
\text { el }\end{array}$} & $\begin{array}{c}\text { Sum of } \\
\text { Square } \\
\mathrm{s}\end{array}$ & Df & $\begin{array}{l}\text { Mea } \\
n \\
\text { Squa } \\
\text { re }\end{array}$ & $\mathrm{F}$ & $\begin{array}{c}\text { Sig } \\
\cdot\end{array}$ \\
\hline \multirow[t]{3}{*}{1} & $\begin{array}{l}\text { Regres } \\
\text { sion }\end{array}$ & $\begin{array}{l}18180 \\
36\end{array}$ & 2 & $\begin{array}{l}909 \\
0,18\end{array}$ & $\begin{array}{c}87 \\
, 5 \\
01 \\
\end{array}$ & $\begin{array}{c}, 0 \\
00 \\
\text { b }\end{array}$ \\
\hline & $\begin{array}{l}\text { Residu } \\
\text { al }\end{array}$ & $\begin{array}{c}11531 \\
43 \\
\end{array}$ & 111 & $\begin{array}{l}103, \\
887\end{array}$ & & \\
\hline & Total & $\begin{array}{c}29711 \\
79\end{array}$ & 113 & & & \\
\hline \multicolumn{7}{|c|}{$\begin{array}{l}\text { a. Dependent Variable: Kinerja Guru } \\
\text { Madrasah }\end{array}$} \\
\hline \multicolumn{7}{|c|}{$\begin{array}{l}\text { b. Predictors: (Constant), Peranan Komite Madrasah, } \\
\text { Kepemimpinan Kepala Madrasah }\end{array}$} \\
\hline
\end{tabular}

Hasil uji $F$ menunjukkan nilai signifikansi dari uji $\mathrm{F}$ adalah 0,000 $(p<0,05)$ sehingga disimpulkan bahwa terdapat pengaruh secara bersama dari kepemimpinan kepala madrasah dan peranan komite madrasah secara langsung terhadap kinerja guru madrasah.

Setelah dilakukan uji f dan uji t, kemudian dilakukan uji koefisien determinasi. Berikut merupakan hasil dari uji koefisien determinasi.

Tabel 17 Hasil Uji Koefisien Determinasi

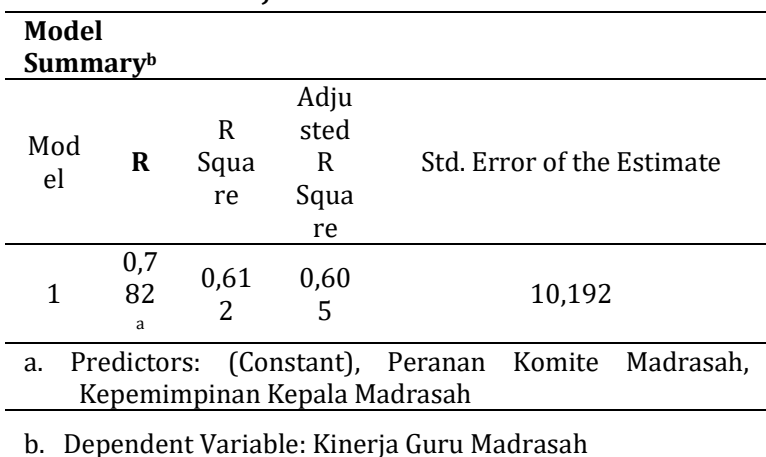

Berdasarkan tabel 17, diperoleh nilaikoefisien determinasi (Adjusted ${ }^{2}$ ) sebesar 0,605. Ini berarti bahwa 60,5\% variasi kinerja guru madrasah dapat dijelaskan oleh variasi kepemimpinan kepala madrasah dan peranan komite madrasah sebesar $60,5 \%$ sedangkan $39,5 \%$ dijelaskan oleh faktor lain selain kedua variabel bebas tersebut. 


\section{Pembahasan}

\section{a. Pengaruh Kepemimpinan Kepala Madrasah terhadap Kinerja Guru Madrasah Aliyah di Kabupaten Banjarnegara}

Hasil uji hipotesis penelitian menunjukkan bahwa terdapat pengaruh signifikan kepemimpinan kepala madrasah terhadap kinerja guru yang ditunjukkan dengan nilai signifikansi dari uji T sebesar 0,000 $(\mathrm{p}<0,05)$. Pengaruh tersebut bersifat positif yang disimpulkan dari hasil uji $\mathrm{T}$ sebesar 5,983, artinya semakin baik kepemimpinan kepala madrasah, semakin baik pula kinerja guru Madrasah Aliyah di Kabupaten Banjarnegara. Hasil analisis deskriptif menunjukkan bahwa kepemimpinan kepala Madrasah Aliyah di kabupaten Banjarnegara menunjukkan kategori kepemimpinan sedang. Hal ini diduga bahwa kepala Madrasah Aliyah di kabupaten Banjarnegara dianggap mempunyai kemampuan yang cukup baik (sedang) dalam melakukan tugasnya untuk menggerakkan, mengerahkan, membimbing, melindungi, memberi teladan, memberi dorongan, dan memberi bantuan terhadap sumber daya manusia di madrasah sehingga dapat didayagunakan secara maksimal untuk mencapai tujuan yang telah ditetapkan.

Kepala Madrasah Aliyah di kabupaten Banjarnegara dianggap mampu sebagai manajer pendidikan yang bertanggungjawab atas seluruh komponen madrasah, mampu berupaya meningkatkan mutu pendidikan yang berorientasi kepada pemakai, baik internal (peserta didik) maupun eksternal(komite madrasah dan masyarakat), pemerintah, dan menciptaan iklim kondusif bagi terwujudnya perubahan dan pengembangan madrasah. Kepala Madrasah Aliyah di kabupaten
Banjarnegara sebagai manajer mampu melakukan penilaian terhadap kinerja guru. Penilaian penting dilakukan mengingat fungsinya sebagai alat motivasi pimpinan kepada guru yang akan berdampak pada kinerja guru dalam kualitas pengajaran. Guru yang puas akan pemberian motivasi kepala madrasah maka dia akan bekerja dengan sukarela yang akan membuat kinerja guru meningkat.

Dalam paradigma baru manajemen pendidikan, seorang kepala madrasah harus melakukan peranannya sebagai pimpinan dengan menjalankan fungsi sebagai educator, manager, administrator, supervisor, leader innovator dan motivator (Mulyasa, 2009:98). Lebih lanjut, Mulyasa menyebutkan kepemimpinan kepala madrasah berkaitan dengan berbagai tugas dan fungsi yang harus diembannya dalammewujudkan madrasah efektif, produktif, mandiri, dan akuntabel (Mulyasa, 2011:22). Kepemimpinan kepala madrasah yang efektif adalah kepemimpinan yang mampu memberdayakan seluruh potensi yang ada di madrasah dengan optimal sehingga guru, staf, dan pegawai lainnya merasa ikut terlibat dalam pencapaian tujuan dan sasaran yang telah ditetapkan oleh madrasah. Kepemimpinan kepala madrasah yang efektif adalah kepemimpinan yang mampu memberikan inspirasi dan teladan yang baik bagi guru dan staf pegawai lainnya.

Hasil penelitian ini menunjukkan adanya indikasi yang positif karena sebagian besar guru memberi penilaian yang positif tentang kualitas kepemimpinan kepala madrasah. Penilaian yang positif dari para guru tersebut dapat menjadi cerminan bahwa kepala madrasah cukup berhasil menjadi pemimpin yang baik bagi guru Madrasah 
Aliyah di kabupaten Banjarnegara dan mampu mengantarkan madrasah yang dipimpinannya menuju tujuan utama dari pendidikan, yaitu menciptakan sumberdaya manusia yang berkualitas.

Sallis (1993:86) mengungkapkan bahwa pemimpin harus memiliki visi dan mampu menerjemahkan visi ke dalam kebijakan yang jelas dan tujuan yang spesifik. Peran pemberdayaan guru bisa berwujud pelatihan yang terkait dengan pengembangan kompetensi guru. Aspek penting dari peran kepemimpinan dalam pendidikan adalah memberdayakan para guru dan memberi mereka wewenang yang luas untuk meningkatkan pembelajaran para pelajar.

\section{b. Pengaruh Peranan Komite Madrasah terhadap Kinerja Guru Madrasah Aliyah di Kabupaten Banjarnegara}

Berdasarkan hasil penelitian menunjukkan bahwa terdapat pengaruh signifikan peranan komite madrasah terhadap kinerja guru, hal ini ditunjukkan oleh nilai uji T sebesar 3,704 sedangkan signifikansi dari hasil uji $\mathrm{T}$ adalah 0,000 $(p<0,05)$,pengaruh tersebut bersifat positif, yaitu semakin baik peranan komite madrasah semakin baik pula kinerja guru madrasah. Hasil analisis deskriptif menunjukkan bahwa peran komite dalam kategori sedang yaitu $60,53 \%$. Peran komite sekolah yang cukup baik di Madrasah Aliyah di Kabupaten Banjarnegara menunjukkan adanya rasa tanggung jawab yang cukup baik dan peran serta masyarakat dalam mengembangkan sekolah yang bermuara pada mutu pendidikan secara keseluruhan.

Peran komite madrasah sebagai pendukung dalam bentuk dukungan komite madrasah bisa berupa materil dan moril. Dukungan moril berupa pemantauan dan masukan atau motivasi terhadap kondisi dari pada tenaga pendidik atau guru dan non pendidik (staf karyawan). Dukungan yang harus diberikan oleh komite madrasah secara langsung dapat membantu meningkatkan kinerja guru, seperti peningkatan kesejahteraan guru-guru dalam bentuk tambahan dana (untuk transportasi) jika guru melaksanakan tugas ke pihak eksternal madrasah dan menentukan dan memilih guru yang dianggap berprestasi. Selain itu, dukungan yang diberikan juga berupa pemantauan (melihat kondisi fisik) kondisi sarana dan prasarana yang ada di madrasah. Melakukan koordinasi dukungan sarana dan prasrana di madrasah, memantau kondisi anggaran pendidikan madrasah, dan mengevaluasi pelaksanaan dukungan anggaran dan program madrasah.

\section{c. Pengaruh Kepemimpinan Kepala Madrasah dan Peranan Komite Madrasah Terhadap Kinerja Guru Madrasah Aliyah di Kabupaten Banjarnegara}

Pengaruh kepemimpinan kepala madrasah dan peranan komite madrasah terhadap kinerja guru di Madrasah Aliyah yang ada di Kabupaten Banjarnegara, dapat diterima dan telah teruji pada taraf kepercayaan 95\%. Selanjutnya dapat diinterprentasikan bahwa kepala madrasah dan peranan komite madrasah secara bersama-sama berpengaruh terhadap kinerja guru Madrasah Aliyah yang ada di Kabupaten Banjarnegara. Oleh karena itu kinerja guru tidaklah ditentukan oleh faktor tunggal, melainkan terdapat sejumlah faktor yang dapat mempengaruhinya. Faktor-faktor itu antara lain: fungsi kepemimpinan kepala madrasah, kinerja komite madrasah, keefektifan madrasah, dan banyak faktor yang lainnya. Hal tersebut didukung pula oleh sarana prasarana pendidikan, 
fasilitas media pembelajaran, serta sumber belajar yang memadai baik mutu maupun jumlahnya, biaya yang mencukupi, manajemen yang tepat, serta lingkungan yang mendukung. Berdasarkan hasil penelitian dapat dijelaskan bahwa sebesar 60,50\% menyatakan kepemimpinan kepala madrasah dan peranan komite madrasah memiliki pengaruh terhadap kinerja guru Madrasah Aliyah di Kabupaten Banjarnegara. Peranan komite madrasah dalam menjalankan tugasnya sebagai mitra madrasah dikategorikan cukup baik dan dapat diterima oleh kepala madrasah, guru dan pegawai.

Sedangkan faktor yang paling dominan pengaruhnya terhadap kinerja guru madrasah Madrasah Aliyah di Kabupaten Banjarnegara adalah kepemimpinan kepala madrasah yang paling dominan karena mempunyai nilai koefisien beta regresi yang lebih tinggi dibandingkan dengan koefiseien beta peranan komite madrasah yaitu 0,541. Wuradji (2009:108) menyatakan bahwa peran kepala madrasah dalam penyelenggaraan pembelajaran merupakan peran yang paling tinggi bobotnya dibandingkan dengan dengan peran-peran yang lain. Hal ini cukup beralasan karena tugas utama madrasah adalah menyelenggarakan pendidikan dan pengajaran.

\section{PENUTUP}

\section{Simpulan}

Berdasarkan hasil analisis data dan pembahasan hasil penelitian dapat disimpulkan bahwa (a) Terdapat pengaruh kepemimpinan kepala madrasah dan peranan komite madrasah di Madrasah Aliyah Negeri (MAN) yang ada di Kabupaten Banjarnegara. (b) Terdapat pengaruh peranan komite madrasah di Madrasah Aliyah Tanbihul Ghofilin Bawang, Madrasah Aliyah Al Hidayah Purworeja Klampok, dan Madrasah Aliyah Nurulhikmah Kalibening. (c) Tidak terdapat pengaruh kepemimpinan kepala madrasah dan peranan komite madrasah di Madrasah Aliyah Cokroaminoto Karangkobar, Madrasah Aliyah GUPPI Rakit, Madrasah Aliyah Cokroaminoto Pagedongan 1, dan Madrasah Aliyah Muhammadiyah Sigaluh.

\section{Saran}

Berdasarkan penelitian ini saran peneliti meliputi (a) Bagi peneliti mendatang, dengan adanya penelitian ini diharapkan dapat menjadi pertimbangan untuk mengadakan penelitian lebih lanjut mengenai faktor-faktor yang mempengaruhi kinerja guru Madrasah Aliyah di Kabupaten Banjarnegara pada madrasah yang belum diteliti. Selain itu, perlu diadakan penelitian lain untuk mengungkap faktor-faktor yang mempengaruhi kinerja guru Madrasah Aliyah di luar wilayah Kabupaten Banjarnegara.

(b) Bagi komite madrasah, diharapkan lebih memahami dengan jelas apa yang menjadi fungsi dan perannya dalam membantu meningkatkan kualitas pendidikan di madrasah. (c) Bagi kepala madrasah, diharapkan dapat mengambil keputusan seharusnya melibatkan pertimbangan dari dewan guru, komite madrasah maupun pihak yang dianggap berkepentingan agar terjadi hubungan yang bersinergi dan baik bagi seluruh pihak. (d) Bagi guru, hendaknya terus termotivasi untuk belajar dan semakin meningkatkan potensi diri demi kelancaran kegiatan belajar mengajar dengan kondisi yang terbatas agar pendidikan di Indonesia khususnya pendidikan madrasah semakin maju. 


\section{DAFTAR PUSTAKA}

Carudin. (2011). Pengaruh Kepemimpinan Kepala Sekolah dan Iklim Kerja Terhadap Kinerja Guru SMK Negeri se-Kabupaten Indramayu Tahun Pelajaran 2010/2011. Invotec. Volume VII, No. 2, Agustus 2011. Hlm. 137.

Ismail, Taufik. (2017). Pengaruh Kepemimpinan Kepala Sekolah, Kompensasi, Motivasi Kerja, terhadap Kinerja Guru SD Negeri se-Kecamatan Ngamprah. Jurnal Administrasi Pendidikan. Volume XXIV Nomor 1 April 2017. Hlm. 66.

Mahmud, Hanifudin. (2017). Model dan Pendekatan Supervisi Kepala Sekolah dalam Meningkatan Kinerja Guru PAI di SMP Negeri 1 Limpung Kabupaten Batang. Tesis. Universitas Sains Alquran. Wonosobo: tidak diterbitkan.

Mulyasa. (2009). Menjadi Guru Profesional. Bandung: PT Remaja Rosdakarya.

Mulyasa, (2011). Manajemen dan Kepemimpinan Kepala Sekolah. Jakarta: PT Bumi Aksara.

Sallis, E. (1993). Total Quality Management in Education. London: Kogan Paged Limited.

Sari, Triyantika. (2017). Pengaruh Peran Kepemimpinan Kepala Sekolah dan Peran Komite Sekolah Terhadap Kinerja Guru SD Negeri di Bandar Lampung. Tesis. Universitas Lampung. Bandar Lampung: tidak diterbitkan.

Semiawan, Conny R. (2010). Metode Penelitian Kualitatif. Jakarta:Grasindo.

Sobirin. (2018). Kepala Sekolah Guru dan Pembelajaran. Bandung: Nuansa.

Sugiyono. (2010). Metode Penelitian Pendidikan Pendekatan Kuantitatif, Kualitatif, dan R\&D. Bandung: Alfabeta.

Tim Penyusun Kamus Pusat Pembinaan dan Pengembangan Bahasa. (1991). Kamus Besar Bahasa Indonesia (Edisi kedua). Jakarta: Balai Pustaka.

Wuradji. (2009). The Education Leadership: Kepemimpinan Transformasional. Yogyakarta: Gama Media.

Yusnidar. (2014). Kepemimpinan Kepala Madrasah dalam Meningkatkan Kinerja Guru pada Madrasah Aliyah Negeri Model Banda Aceh. Jurnal Ilmiah Didaktika. Vol. XIV Nomor 2, Februari 2014. Hlm. 346. 